\title{
Rahasia Meede dan Amnesia Sejarah: Belajar Memaknai Sejarah Lewat Sastra Populer
}

\author{
Khothibul Umam \\ Fakultas Ilmu Budaya, Universitas Diponegoro \\ khothibul.umam@live.undip.ac.id
}

\begin{abstract}
Rahasia Meede by E.S. Ito is a popular novel with a historical theme that was published in 2007. The novel tells of a treasure hunt using various kinds of characters and events that really happened in the real world. To analyze Rahasia Meede, the approach used is a sociology of literature that assesses text as a mirror of society. The study of the text is not preceded by the study of the structure of the text but directly on the historical and sociopolitical aspects in the text. The result of his research is to make a treasure hunt story, a historical text can be given to the reader with a new and entertaining perspective.

Keywords: history, novels, popular literature.
\end{abstract}

\section{Intisari}

Rahasia Meede karya E.S. Ito adalah sebuah novel populer dengan tema sejarah yang terbit tahun 2007. Novel tersebut menceritakan sebuah perburuan harta karun dengan memakai berbagai macam tokoh dan peristiwa yang benar-benar terjadi di dunia nyata. Untuk menganalisis Rahasia Meede, pendekatan yang dipakai adalah sosiologi karya sastra yang menilai teks sebagai cermin masyarakat. Telaah teks tidak didahului oleh penelitian struktur teks tetapi langsung pada aspek sejarah dan sosio-politik dalam teks. Hasil penelitiannya adalah dengan membuat cerita perburuan harta karun, sebuah teks sejarah bisa diberikan kepada pembaca dengan perspektif baru dan menghibur.

Kata Kunci: Sejarah, novel, sastra popular.

\section{Pendahuluan}

Pada tahun 2007 terbit sebuah novel yang berjudul Rahasia Meede: Misteri Harta Karun VOC karya E.S. Ito. Dengan mengambil latar waktu yang hanya berkisah sekitar 24 jam, Rahasia Meede langsung mengingatkan kita pada resep-resep Dan Brown dalam menulis Angels \& Demons, Digital Fortress, Deception Point dan tentu saja The Da Vinci Code. Kisah yang bercerita tentang perburuan emas VOC pun secara tidak langsung mengingatkan pada film National Treasures yang dibintangi oleh Nicholas Cage.

Harus diakui, resep fiksi ala E.S. Ito yang meramu fakta dan fiksi dengan balutan thriller sejarah lumayan baru dalam dunia Sastra Indonesia. Tidak banyak yang menulis novel dengan genre tersebut. Mungkin yang paling terkenal sebelum Rahasia Meede adalah Pacar Merah Indonesia karya Matu Mona yang menyitir kisah hidup Tan Malaka dalam kejaran intel Hindia Belanda. 
Cerita dengan genre detektif, mata-mata, dan kejahatan, mendapatkan posisi sendiri dalam ranah sastra populer. Dengan memasukkan berbagai macam peristiwa dan tokoh faktual dalam sastra populer, membuat sejarah dikemas menjadi sangat asyik bagi para pembaca muda.

\section{Metode Penelitian}

Membaca Rahasia Meede, yang banyak memasukkan tokoh dan peristiwa faktual dalam ceritanya, maka pendekatan yang relevan digunakan adalah sosiologi dan sejarah. Dalam kaitan ini tentu saja pendekatan sosiologi sastra perlu sedikit penulis uraikan.

Sebagai multidisiplin, maka ilmu-ilmu yang terlibat dalam sosiologi sastra adalah sastra dan sosiologi. Dengan pertimbangan bahwa karya sastra juga memasukkan aspekaspek kebudayaan yang lain, maka ilmu-ilmu yang juga terlibat adalah psikologi, sejarah, filsafat, agama, ekonomi, dan politik.

Untuk menganalisis Rahasia Meede, pendekatan yang dipakai adalah sosiologi karya sastra yang menilai teks sebagai cermin masyarakat. Telaah teks tidak didahului oleh penelitian struktur teks tetapi langsung pada aspek sejarah dan sosio-politik dalam teks. Seluruh data untuk penelitian ini dikumpulkan melalui studi pustaka. Hasil analisis kemudian akan ditampilkan dalam bentuk deskriptif, yaitu menampilkan kenyataan yang ditemukan dalam teks apa adanya.

\section{Hasil dan Pembahasan}

\section{Realitas dalam Rahasia Meede}

Tokoh dan fakta sejarah juga bertaburan di novel ini, disertai dengan data-data nama tempat yang persis aslinya. Hal ini tidaklah mengherankan, karena salah satu syarat sastra populer/massa adalah harus "realis". "Realis" di sini tidak berarti "sama dengan realita" atau pun "merujuk pada realita tertentu", melainkan suatu dunia fiktif yang memberi kesan mirip dengan dunia yang kita kenal sehari-hari, atau Vraisemblable (seakan-akan nyata) ${ }^{1}$.

Tema sejarah merupakan salah satu tema yang tiada habisnya dipakai dalam eksplorasi kreatifitas dunia sastra. Baik cerita yang berlatarbelakang peristiwa sejarah ataupun kisah yang hanya mencomot tokoh sejarah sebagai pelakunya. Rahasia Meede juga seperti itu. Novel ini “meminjam” Bung Hatta, JP. Coen, M. Husni Thamrin, dan

\footnotetext{
${ }^{1}$ Baca Apsanti Djokosujatno, "Estetika dan Nilai Sastra Massa", dalam Majalah Horison edisi 06/XXVIII.
} 
banyak tokoh lain. Ada beberapa tokoh yang diberi dialog, ada pula yang disinggung sekilas dalam cakapan antartokoh.

"Peminjaman" tokoh sejarah ini dilakukan untuk bukan hanya sebagai tempelan. Tokoh sejarah dibutuhkan dalam kerangka pembangun cerita. Meskipun memakai tokoh cerita yang menjadi pelaku sejarah, teks dalam novel ini bukanlah dokumen sejarah. Benarlah di dalamnya terdapat acuan pada fakta-fakta sejarah, peristiwa dan tempat serta orang-orang di dalam kenyataan, tetapi pemberian makna secara mimetik seperti halnya dalam penulisan sejarah pastilah keliru² ${ }^{2}$

Rahasia Meede sebagian besar berlatar tempat di Indonesia. Semua nama tempat ada di dunia nyata. Seperti Kota Tua Jakarta, Istana Negara, Monas, Boven Digul, Banda Neira, hingga SMA Taruna Nusantara, Magelang. "Kesan riil” dalam Rahasia Meede ini memang menjadi salah satu ciri utama dalam khasanah sastra populer. "Kesan riil" ini dibangun melalui sejumlah teknik dan prosedur tertentu, seperti sorot balik, motivasi, nama diri, nama-nama jalan/kota yamg kita kenal sebagai suatu kenyataan geografis ${ }^{3}$.

Rahasia Meede, yang mempunyai sub judul Misteri Harta Karun VOC, memang belum terbukti ada atau tidak dalam dunia nyata. Namun, dalam sastra populer, hal tersebut bisa ditutupi dengan pentingnya detil, dan Rahasia Meede cukup detil mendedahkan cerita yang dilukiskan secara rinci sehingga menimbulkan kesan riil.

Selayaknya cerita detektif atau thriller lainnya, detil-detil peristiwa sangat diperhatikan dalam novel ini. Hal ini untuk memberikan efek logis yang menjadi tuntutan pembaca. Kelogisan cerita sangat berguna untuk membangun suspense atau ketegangan yang mencapai klimaks di akhir cerita.

Selain itu, kerumitan alur juga menjadi salah satu tuntutan selera cerita dengan berlatarbelakang konspirasi. Jadi, selain karakterisasi harus kuat, dibutuhkan banyak tokoh dengan alur masing-masing yang kehadirannya harus memberi kesan logis.

Dalam Rahasia Meede ada tokoh Guru Uban, seorang guru sejarah yang sangat misterius dan dihormati oleh lingkungannya. Ada Kalek, pemimpin organisasi anarkis yang sangat pandai bercerita tentang sejarah Indonesia dalam sudut pandang yang berbeda dari buku-buku sejarah. Ada Batu Noah Gultom, seorang wartawan muda ambisius yang mempunyai hubungan masa lalu dengan Kalek. Ketiga tokoh tersebut secara "kebetulan" bertemu dalam satu titik cerita yang saling berkaitan.

\footnotetext{
2 Lihat Teeuw, "Kenyataan dalam Babad dan Sejarah", dalam Sastra dan Ilmu Sastra (2015).

3 Apsanti Djokosujatno, "Estetika dan Nilai Sastra Massa", dalam Majalah Horison edisi 06/XXVIII
} 


\section{Rahasia Meede dan Amnesia Sejarah}

Tuntutan abad ini adalah rasa ingin tahu dan emosi yang berlebih-lebihan. Rasa ingin tahu tersebut dibedakan atas ingin tahu hal yang telah terjadi (curiosite) dan ingin tahu hal yang akan terjadi (suspense), yang dengan jelas menimbulkan ketegangan ${ }^{4}$. Keinginan tahu hal yang telah terjadi menimbulkan ketegangan intelektual. Hal tersebut dipunyai oleh novel detektif, konspirasi, atau thriller semacam Rahasia Meede.

Sejarah memang menjadi tema utama dalam novel ini. Frasa "Misteri Harta Karun VOC" adalah kuncinya. Pemburu harta karun haruslah seorang yang tahu tentang sejarah. Tidak bisa tidak.

Setidaknya ada beberapa tokoh dalam novel Rahasia Meede yang sangat paham terhadap sejarah. Yang pertama adalah Guru Uban. Seorang guru sejarah di SMA Abdi Bangsa, Bojonggede. Guru Uban adalah seorang brahmacari, orang yang hidup membujang dan hidup vegetarian. Ia mengajar sejarah dengan dongeng yang memukau murid-muridnya. Dalam mengajar sama sekali ia tidak menyentuh buku paket sejarah. Pelajaran sejarah baginya harus disampaikan dengan menarik dan interaktif. Selain itu ia selalu mengajak murid-muridnya untuk berpikir kritis dengan belajar dari kesalahan masa lalu.

"Kalian tahu bagaimana orang-orang dulu menguasai pengetahuan?" tanya Guru Uban lagi. Kali ini dia ajukan ke seluruh penjuru kelas. Tetap tidak terdengar jawaban. Guru Uban menelan ludah. Sistem pendidikan apa yang diwarisi anakanak ini hingga bisu tidak bersuara?"Anakku, coba kamu jawab." tunjuknya pada murid laki-laki berambut tipis.

"Emmm ... perang, Pak," jawab murid itu ragu.

"Bisa juga, tetapi tidak sepenuhnya tepat jawabanmu itu. Yang lain?"

"Sihir, mantra, dan santet, Pak," terdengar seruan dari pojok belakang. Yang berseru langsung menyembunyikan kepala. Jawabannya disertai tawa penjuru kelas. Guru Uban tersenyum masam.

"Ada lagi?" Hilang sudah semua suara tadi. Guru Uban memungut buku teks dari mejanya. Lalu, dia acungkan tinggi-tinggi. "Dengan ini. Buku! Itu sebabnya kalian harus rajin membaca." (Hal. 58)

Guru Uban mencoba membongkar kebebalan murid-muridnya dengan pelajaran sejarah. Guru Uban mencoba melawan arus gaya pengajaran konvensional hasil sistem pendidikan mutakhir yang sama sekali tidak mencerdaskan murid-muridnya.

\footnotetext{
${ }^{4}$ Ibid.
} 
Tokoh selanjutnya adalah Cathleen Zwinckel, seorang mahasiswi S2 Leiden yang cantik jelita. Ia mempunyai proyek penelitian di Indonesia yang memaksanya bersinggungan dengan berbagai kalangan di Indonesia, mulai dari birokrat, akademisi hingga orang-orang LSM. Cathleen pun berhadap-hadapan secara langsung dengan Rian, seorang aktivis LSM yang apatis terhadap sejarah.

"Apalah arti sebuah jejak? Ia bisa dihapus atau setidaknya dimanipulasi menjadi bentuk yang berbeda. Kejadian di masa lalu, tidak berarti banyak untuk masa sekarang. Tiap generasi meretas jalannya sendiri. Hubungan kausalitas tidak memiliki makna. Jika masa lalu bisa menentukan masa depan, lantas apa gunanya kita bekerja saat ini? Aku termasuk orang yang skeptis terhadap studi sejarah. Pada abad percepatan teknologi informasi ini, studi sejarah seharusnya dihapuskan. Runtuhnya tembok Berlin dan pembantaian Tiananmen hanya bermakna pada 1989, sekarang tidak lagi berarti apa-apa. Demikian juga dengan cerita kedaulatan Indonesia, hanya bermakna pada 27 Desember 1949, juga tidak berarti banyak untuk saat ini. Tiap tindakan hanya terkait dengan tempo waktu peristiwanya. Dan, ingat...." Rian menaikkan satu jari telunjuknya. "Sejarah adalah milik pihak yang menang. Tidak pernah benar-benar obyektif." (Hal. 126).

Pandangan Rian di atas senada dengan pendapat George Santayana tentang sejarah. "Sejarah adalah sekotak kebohongan tentang peristiwa yang tak pernah terjadi yang dituturkan oleh orang yang tak pernah berada di sana"5. Pendapat Rian adalah otokritik terhadap pelajaran sejarah yang diajarkan oleh Orde Baru pada sekolah-sekolah. Sebagai pemenang, Orde Baru berhak mengajarkan "kebohongan" yang diajarkan dari satu generasi ke generasi lainnya dan akhirnya diterima sebagai kebenaran.

Kedua tokoh selanjutnya adalah Roni Damhuri dan Attar Malaka alias Kalek, dua sahabat semasa SMA di SMA Taruna Nusantara, Magelang. Jalan hiduplah yang membuat dua sahabat ini berbeda. Roni menjadi tentara dalam kesatuan Kopassus, sedangkan Kalek menjadi pemimpin pergerakan anarkis bawah tanah. Dua pilihan hidup yang berbeda ini turut pula membawa perbedaan pada cara mereka memandang sejarah.

Kalek tertawa senang. Bagai reuni setelah bertahun-tahun di sebuah tempat makan yang nyaman di Jakarta. "Begitu cara KNIL mencari tentara Republik di tengah-tengah petani Situjuh tahun 1948. Kau tentu tidak tahu cerita itu, yang kau mengerti hanya, Gajah Mada dan Gajah Mada, ah sialan, Gajah Mada lagi. Agresor dan agitator penaklukan itu."

"Ternyata ada gunanya juga kau sekolah di Taruna Nusantara dulunya," Roni tersenyum mencibir.

"Tentu, aku bisa mengenali penyamaran tentara sebaik apa pun." (Hal. 374).

\footnotetext{
${ }^{5}$ Lihat Bonnie Triyana, "Salah Kaprah dalam Sejarah”, dalam Majalah Historia No. 5 Tahun 1/2012
} 
Sejarah, atau ilmu apapun, memang diajarkan sesuai dengan kepentingan. Sejarah resmi pemerintah pun tidak pernah lepas dari hal tersebut. Dari kutipan di atas bisa kita lihat aplikasi pelajaran sejarah yang dipakai oleh kedua tokoh. Roni sebagai abdi negara, memandang sejarah resmi sebagai sebuah "kitab suci" yang antikritik. Gajah Mada adalah sosok pemersatu Nusantara. Sedangkan Attar yang jalannya menyimpang menjadi pemberontak, memandang Gajah Mada tidak lebih dari seorang konseptor penjajahan terhadap kerajaan-kerajaan lain di Nusantara.

Kelima tokoh di atas masing-masing mewakili pendapat mereka tentang sejarah. Guru Uban sebagai seorang guru sejarah yang mencoba kreatif dalam mengajar, memandang pelajaran sejarah adalah sebuah pelajaran yang penting, yang dapat menjadi modal dalam mengarungi masa depan. Belajarlah dari sejarah! Itu semboyannya.

Senada dengan Guru Uban, Cathleen berada dalam kutub yang sama. Sejarah adalah hasratnya. Namun, posisinya sebagai orang luar membuat ia memandang sejarah bangsa Indonesia dengan lebih obyektif dan kritis. Hal ini bertolak belakang dengan Rian.

Sebagai seorang aktivis dan cendekiawan muda, Rian tentu saja tahu tentang sejarah bangsanya. Meski dalam perkembangannya, mungkin karena sering bersinggungan dengan politik dan kekuasaan, Rian memandang sejarah hanyalah alat, atau yang lebih parah, sejarah adalah sekedar memori seorang pemenang (baca: penguasa). Penulisan sejarah tergantung "men behind the pen"- tergantung siapa yang berkuasa memegang "pena".

Pandangan selanjutnya adalah dari Roni dan Kalek. Dibesarkan dengan pelajaran yang sama, namun arah hidup yang membuat pandangan berbeda. Roni, selaiknya tentara, menerima sejarah sebagai doktrin yang diterima dalam kerangka menjaga keutuhan Negara Kesatuan Republik Indonesia. Tiada boleh tafsir lain selain yang diperintahkan oleh atasan. Perintah adalah perintah, meski bertentang dengan nurani atau kenangan manis masa lalu.

Kalek yang memilih jalan hidup berlawanan, memandang sejarah resmi hanyalah kedok penjajahan baru. Hal tersebut bisa dilihat dari betapa bencinya Kalek pada Gajah Mada. Sosok yang dimitoskan Orde Baru sebagai pelopor pemersatu Nusantara. Pandangan Kalek juga bisa ditafsirkan dengan pandangan Jawa dan Luar Jawa. Telah lama Jawa selalu menjadi pusat dan Luar Jawa terabaikan. Tokoh dari Luar Jawa seperti Kalek dengan sangat tepat menjadi representasi suara dari Luar Jawa yang menuntut kemakmuran yang sama dengan saudaranya di Jawa. 
E.S. Ito dengan secara sadar memberikan alternatif pemaknaan sejarah pada setiap tokoh-tokohnya. Masyarakat Indonesia hanya "belajar sejarah" dan tidak pernah "belajar dari sejarah". Para ahli filsafat sejarah pun masih berdebat apakah sebetulnya sejarahlah yang membentuk manusia (sebagaimana yang diajarkan oleh Hegel dan Marx, misalnya), ataukah sebetulnya manusia sendirilah yang membentuk sejarahnya (sebagaimana dibela secara militan oleh Karl Popper) ${ }^{6}$.

Hal ini sebenarnya senada dengan pendapat Aristoteles yang menganggap penyair (baca: sastrawan) sebenarnya lebih ulung pekerjaannya daripada si sejarawan. Sejarawan mau tak mau terikat pada fakta-fakta yang "kebetulan" pernah terjadi; dia tidak bebas dalam penggarapan bahan-bahan sejarah itu, sedangkan seorang penyair dapat menulis ceritanya sendiri. Penyair, sastrawan, dan seniman secara umum menekankan pemberian makna pada eksistensi manusia, lewat cerita, peristiwa, yang barangkali tidak benar secara faktual, tetapi masuk akal secara maknawi ${ }^{7}$.

Tokoh-tokoh Ito dalam Rahasia Meede memaknai dan memakai pengetahuan sejarah mereka secara cerdas dan bebas. Perkara perburuan harta karun hanyalah sebuah tujuan dan sejarah adalah prosesnya. Rahasia Meede mengajak pembaca untuk tidak mengidap amnesia terhadap sejarah.

Rahasia Meede seperti sebuah proyek JASMERAH (Jangan Sekali-kali Melupakan Sejarah) dengan kemasan hiburan. Setelah membacanya, kita seperti dibimbing untuk mengetahui sejarah Indonesia dengan cara pandang yang lain. Hal ini tidak beda dengan para pembaca Dunia Sophie yang mendadak berbondong-bondong belajar filsafat setelah selesai membacanya.

\section{Simpulan}

Sejarah adalah hal yang serius. Terkadang hal yang serius membuat orang malas mempelajarinya. Rahasia Meede dengan cukup cerdik menyampaikan cerita konspirasi yang dibalut sejarah. Sejarah di sini tentu saja bukan sejarah resmi pemerintah, namun tafsir atas sejarah yang selama ini diajarkan alias otokritik sejarah.

Sejarah adalah milik pemenang dan pemenanglah yang bisa menuliskannya. Sejarah Indonesia diliputi oleh sejarah orang-orang kalah atau dikalahkan dan kisah

\footnotetext{
${ }^{6}$ Lihat Ignas Kleden "Cerita-cerita Pulau Buru: Sejarah dan Nyanyi Burung Kedasih", dalam Sastra Indonesia dalam Enam Pertanyaan: Esai-esai Sastra dan Budaya (2004).

7 Lihat Teeuw, "Sastra dan Penulisan Sejarah", dalam Sastra dan Ilmu Sastra (2015).
} 
mereka sama sekali tidak tercatat. E.S. Ito dengan Rahasia Meede meramu peristiwa demi peristiwa sejarah dalam fiksi yang menghibur.

\section{Daftar Pustaka}

Djokosujatno, Apsanti. "Estetika dan Nilai Sastra Massa", dalam Majalah Horison edisi 06/XXVIII.

Ito, E.S. 2008 (Cetakan ketiga). Rahasia Meede: Misteri Harta Karun VOC. Jakarta: Hikmah.

Kleden, Ignas. 2004. "Cerita-cerita Pulau Buru: Sejarah dan Nyanyi Burung Kedasih", dalam Sastra Indonesia dalam Enam Pertanyaan: Esai-esai Sastra dan Budaya. Jakarta: Pustaka Utama Grafiti.

Merriam-Webster, An Encyclopædia Britannica Company. "Blurb", URL: http://www.merriam-webster.com/dictionary/blurb.

Teeuw, A. 2015 (cetakan kelima). Sastra dan Ilmu Sastra. Bandung: Pustaka Jaya.

Triyana, Bonnie. 2012. "Salah Kaprah dalam Sejarah”, dalam Majalah Historia No. 5 Tahun 1. 